\title{
Termin przedawnienia prawa do odprawy emerytalnej przysługującej na podstawie art. 38 ustawy o wykonywaniu mandatu posła i senatora ${ }^{1}$
}

Limitation period for the right to retirement gratuity mentioned in Article 38 of the Act on the Exercise of the Mandate of a Deputy or Senator (WAP-1036/18): Members of Parliament remain in a nonlabour the so-called systemic employment, which is not regulated by law in a precise manner. The nature of the retirement gratuity entitled under the aforementioned provision of the Act is not clear. There is a possible interpretation, according to which that this gratuity is not a subject to a limitation period of 3 years (pursuant to Article $291 \S 1$ of the Labour Code), but to a 10-year period specified in Article 118 of the Civil Code. However the author claims that the 3-year limitation period provided in labour law is applicable in the discussed situation.

Keywords: pensions and annuities, Deputy, limitation of claims

Słowa kluczowe: emerytury i renty, poseł, przedawnienie roszczeń

Ekspert ds. legislacji BAS; irena.galinska-raczy@sejm.gov.pl.

\section{Przedmiot opinii}

Opinia dotyczy kwestii związanej z zachowaniem uprawnienia do odprawy emerytalnej w następującym stanie faktycznym. W 2009 r. i 2010 r. dwaj posłowie zawodowi, przeszli na emeryturę i nie otrzymali odpraw emerytalnych przysługujących na podstawie art. 38 ustawy z 9 maja 1996 r. o wykonywaniu mandatu posła i senatora ( $\mathrm{z}$ informacji uzyskanych w Biurze Obsługi Posłów wynika, że mimo poinformowania ich o możliwości uzyskania odprawy nie ubiegali się o to świadczenie). Postawiono pytanie, czy w takiej sytuacji prawo do odprawy uległo

1 Opinia prawna na temat terminu przedawnienia prawa do odprawy emerytalnej przystugujacej na podstawie art. 38 ustawy z dnia 9 maja 1996 r. o wykonywaniu mandatu posła i senatora (we wskazanym stanie faktycznym) sporządzona 14 czerwca $2018 \mathrm{r}$. na zlecenie posłów Klubu Parlamentarnego Platforma Obywatelska; BAS-WAP 1036/18. 
przedawnieniu oraz czy mogą o nią wystąpić na koniec obecnej kadencji Sejmu (zwłaszcza z uwagi na art. 40 tej ustawy).

Jednocześnie zwrócono się o wyjaśnienie, jaki jest tryb wypłaty odprawy, w tym czy jest ona wypłacana automatycznie, czy też należy o nią wystąpić.

Opinia została sporządzona $\mathrm{z}$ uwzględnieniem następujących aktów prawnych:

- ustawa z 9 maja 1996 r. o wykonywaniu mandatu posła i senatora, t.j. Dz.U. 2016, poz. 1510, ze zm.; dalej: u.w.m.p.s.,

- ustawa z 17 grudnia 1998 r. o emeryturach i rentach z Funduszu Ubezpieczeń Społecznych, t.j. Dz.U. 2017, poz. 1383, ze zm.,

- ustawa z 26 czerwca 1974 r. - Kodeks pracy, t.j. Dz.U. 2018, poz. 917, ze zm.; dalej: k.p.,

- ustawa z 23 kwietnia 1964 r. - Kodeks cywilny, t.j. Dz.U. 2017, poz. 459, ze zm.; dalej: k.c.

\section{Uzasadnienie}

1. Zgodnie $\mathrm{z}$ art. 38 ust. 1 u.w.m.p.s.: Posłowi $i$ senatorowi, który $w$ trakcie sprawowania mandatu lub w ciagu dwunastu miesięcy po jego wygaśnięciu albo dwóch lat od zakończenia korzystania $z$ urlopu bezpłatnego, o którym mowa w art. 29 $i$ art. 30, przechodzi na emeryture albo rente, przysługuje jednorazowa odprawa $w$ wysokości trzech uposażeń - przy przejściu na emeryturę oraz jednego uposażenia - przy przejściu na rentę.

Ani ustawa o wykonywaniu mandatu posła i senatora, ani przepisy wykonawcze do tego aktu nie określają trybu wypłaty odprawy wskazanej w powołanym przepisie, nie ma też ustalonego wzoru wniosku o wypłatę, który precyzowałby datę i okoliczności przejścia na emeryturę lub rentę (w tym np. w postaci deklaracji co do tego, czy poseł nie otrzymał odprawy emerytalnej u pracodawcy, co ma znaczenie z punktu widzenia art. 38 ust. 2 u.w.m.p.s. ${ }^{2}$, bowiem w sytuacji, kiedy otrzymałby odprawę u pracodawcy, nie miałby prawa do odprawy w Sejmie ${ }^{3}$ ). Brak takich uregulowań jest pewnym mankamentem, ale podobna sytuacja ma miejsce w przypadku pracowników podlegających powszechnemu prawu pracy, którzy nabywają prawo do odprawy emerytalno-rentowej czy nagród jubileuszowych i nie muszą składać wniosków o ich wypłatę, ale są zobowiązani dostarczyć

2 Przepis ten stanowi, że: [w] razie zbiegu uprawnień, z różnych tytułów, do jednorazowej odprawy $w$ związku z przejściem na emeryturę lub rentę, przysługuje odprawa wybrana przez uprawnionego.

3 W ten sposób jest interpretowany ten przepis przez J. Stelinę w komentarzu do art. 38 u.w.m.p.s., [w:] K. Grajewski, J. Stelina, P. Uziębło, Komentarz do ustawy o wykonywaniu mandatu posła i senatora, Warszawa 2014, s. 456. 
informacje i dokumenty umożliwiające pracodawcy ustalenie, że danej osobie przysługuje takie świadczenie ${ }^{4}$.

Wniosek taki jest konieczny, ponieważ właściwa w tej mierze jednostka organizacyjna Kancelarii Sejmu musi zostać poinformowana o fakcie „przejścia” na emeryturę i dacie tego przejścia, co ma znaczenie zwłaszcza w przypadku tzw. posłów niezawodowych (czyli niepobierających uposażenia poselskiego), którzy nie informują Kancelarii Sejmu o swoim statusie zawodowym, ani jego zmianie, tak jak ma to miejsce w przypadku posłów zawodowych ${ }^{5}$. Wypłata odprawy emerytalnej na podstawie art. 38 ust. 1 u.w.m.p.s. nie może odbywać się zatem w sposób automatyczny, tak jak ma to miejsce w przypadku odprawy parlamentarnej, która jest wypłacana wszystkim posłom, pod warunkiem że nie zostali wybrani na następną kadencję Sejmu oraz nie otrzymali w danej kadencji odprawy emerytalnej lub rentowej. Kancelaria Sejmu ma pełną wiedzę o spełnieniu tych warunków i nie musi zwracać się do posłów o ich potwierdzenie.

2. W art. 38 ust. 1 u.w.m.p.s. zostały ustalone dwie przesłanki nabycia prawa do odprawy:

- fakt „przejścia” na emeryturę (rentę) oraz

- czas (moment), w którym to przejście następuje.

Przez określenie "przejście na emeryturę" należy rozumieć nie tylko nabycie uprawnień emerytalnych (w sensie spełnienia warunków określonych np. w ustawie z 17 grudnia 1998 r. o emeryturach i rentach z Funduszu Ubezpieczeń Społecznych ${ }^{6}$ ), ale również rozpoczęcie pobierania świadczenia emerytalnego,

4 A. Rycak w komentarzu do art. 38 ust. 1 ustawy o pracownikach samorządowych stwierdza: Ponieważ nie jest z góry pewne, czy wniosek ubezpieczonego o emeryturę lub rentę $z$ tytułu niezdolności do pracy złożony do organu rentowego zakończy się faktycznym uzyskaniem pozytywnej decyzji administracyjnej, pracodawca ma prawo wstrzymać się z wypłata odprawy do dnia uzyskania od ubezpieczonego kopii prawomocnej decyzji organu rentowego (ZUS, KRUS), A. Rycak, M. Rycak, J. Stelina, J. Stępień, Ustawa o pracownikach samorządowych. Komentarz, Warszawa 2016.

5 Zgodnie z uchwałą nr 26 Prezydium Sejmu z 25 września 2001 r. w sprawie szczegółowych zasad i trybu wypłacania uposażenia poselskiego oraz odprawy parlamentarnej poseł ubiegający się o wypłatę lub przyznanie uposażenia składa wniosek, w którym w sposób szczegółowy informuje o aktywności zawodowo-gospodarczej oraz prawie do świadczeń emerytalno-rentowych, a jednocześnie zobowiązuje się do powiadomienia o wszelkich zmianach w tym zakresie.

$6 \quad$ Zgodnie z art. 100 tej ustawy: 1. Prawo do świadczeń określonych $w$ ustawie powstaje $z$ dniem spetnienia wszystkich warunków wymaganych do nabycia tego prawa, $z$ zastrzeżeniem ust. 2.

2. Jeżeli ubezpieczony pobiera zasiłek chorobowy, świadczenie rehabilitacyjne lub wynagrodzenie za czas niezdolności do pracy wypłacane na podstawie przepisów Kodeksu pracy, prawo do emerytury, renty z tytułu niezdolności do pracy lub renty szkoleniowej powstaje z dniem zaprzestania pobierania tego zasiłku, świadczenia lub wynagrodzenia. 
które wiąże się z rozwiązaniem stosunku pracy. W literaturze wskazuje się, że w rozumieniu art. $92^{1}$ k.p. ${ }^{7}$ : Spetnienie przez pracownika warunków uprawniajacych do emerytury lub renty, czyli po prostu nabycie prawa do tych świadczeń, nie wystarcza do przejścia na emeryturę lub rentę. Przejście na emeryturę lub rente musi poprzedzać przyznanie przez organ rentowy jednego z tych świadczeń. Jednak także przyznanie świadczenia nie stanowi samo przez się o przejściu na emeryturę lub rentę. Przejście na emeryturę lub rentę nie jest wprawdzie możliwe bez spetnienia warunków uprawniających do tych świadczeń, ale ich spełnienie jest tylko jedna, pierwsza w kolejności z przesłanek koniecznych do przejścia na emeryture (rentę). Przejście na emeryturę lub rentę następuje bowiem zawsze i tylko przez rozwiązanie stosunku pracy.

W podobny sposób pojęcie „przejście na emeryturę” jest rozumiane również w orzecznictwie, np. w wyroku z 14 czerwca 2012 r. (sygn. akt I PK 229/11) ${ }^{9}$ oraz w wyroku z 2 października 2013 r. (sygn. akt II PK 14/13) ${ }^{10}$ Sąd Najwyższy stwierdził, że przejściem na emeryturę lub rentę w rozumieniu art. $92^{1} \$ 1$ k.p. i art. 38 ust. 3 ustawy o pracownikach samorządowych (który został sformułowany w sposób podobny jak art. 38 ust. 1 u.w.m.p.s. ${ }^{11}$ ) jest zmiana statusu pracownika lub pracownika emeryta (rencisty) na status wyłącznie emeryta (rencisty). W orzecznictwie przyjmuje się, że „przejście na emeryturę” następuje przez ustanie stosunku pracy ${ }^{12}$.

Uwzględniając powyższe, za każdym razem, kiedy poseł występuje o wypłatę odprawy, należałoby ustalić, czy i kiedy miało miejsce rozwiązanie stosunku pracy oraz czy i kiedy poseł rozpoczął pobieranie świadczenia emerytalnego (rentowego).

3. Przepis ust. 2 nie ma zastosowania do emerytury, o której mowa $w$ dziale II rozdział 1.

7 Art. 921. \$ 1. Pracownikowi spetniajacemu warunki uprawniajace do renty z tytułu niezdolności do pracy lub emerytury, którego stosunek pracy ustał w związku z przejściem na rentę lub emeryturę, przysługuje odprawa pieniężna w wysokości jednomiesięcznego wynagrodzenia.

$\$$ 2. Pracownik, który otrzymał odprawę, nie może ponownie nabyć do niej prawa.

8 B. Wagner [w:] Kodeks pracy. Komentarz, red. L. Florek, 2017, LEX.

9 LEX nr 1232231.

10 LEX nr 1388658. Zob. także wyrok z 1 kwietnia 2015 r., sygn. akt II PK 136/14, LEX nr 1666017.

11 3. W związku z przejściem na emeryturę lub rentę z tytułu niezdolności do pracy przystuguje jednorazowa odprawa w wysokości:

1) po 10 latach pracy - dwumiesięcznego wynagrodzenia;

2) po 15 latach pracy - trzymiesięcznego wynagrodzenia;

3) po 20 latach pracy - sześciomiesięcznego wynagrodzenia.

12 Przejście to następuje z reguły jednocześnie z rozwiązaniem stosunku pracy, ale może też nastąpić później ze względu na datę złożenia wniosku lub korzystanie z zasiłku chorobowego (wyrok SN z 14 czerwca 2012 r., sygn. akt I PK 229/11, oraz wyrok SN z 13 stycznia 2011 r., sygn. akt III PK 18/10, LEX nr 1120416). 
3. Co do czasu „przejścia” przepis art. 38 ust. 1 u.w.m.p.s. wskazuje trzy okresy: „W trakcie sprawowania mandatu”, 12 miesięcy po wygaśnięciu mandatu, dwa lata od zakończenia poselskiego urlopu bezpłatnego. Z wyjaśnień przekazanych przez posłów wynika, że przejście na emeryturę miało miejsce w 2009 r. i 2010 r., a zatem chodzi o przejście na emeryturę „w trakcie sprawowania mandatu”.

W związku z ogólną formułą zawartą w art. 38 ust. 1 u.w.m.p.s. „W trakcie sprawowania mandatu" można mieć wątpliwości, czy określenie to odnosi się do danej kadencji (czy chodzi o przejście na emeryturę w trakcie danej kadencji), czy też można je odnosić do kolejnych kadencji, w przypadku gdy poseł zostaje ponownie wybrany.

Za pierwszą interpretacją przemawia charakter odprawy jako jednorazowego świadczenia związanego ze zmianą statusu zawodowego danej osoby: $\mathrm{z}$ pracownika na status emeryta (rencisty) oraz art. 40 u.w.m.p.s. i przepisy wykonawcze do tego aktu. $Z$ literalnego brzmienia fragmentu art. 38 ust. 1 u.w.m.p.s.: „który przechodzi” (a nie np. przeszedł) wynika, że wypłata odprawy powinna mieć miejsce $\mathrm{w}$ okresie bliskim zdarzeniu, jakim jest przejście na emeryturę. Za zbiegiem czasowym realizacji prawa do odprawy z momentem przejścia na emeryturę przemawia również charakter świadczenia, jakim jest odprawa emerytalna. Jako powszechny należy przyjąć pogląd o socjalnym charakterze tego świadczenia, polegającym na rekompensowaniu pracownikowi utraty zatrudnienia w związku z zaistnieniem sytuacji życiowych objętych ryzykiem rentowym lub emerytalnym ${ }^{13}$. Interpretacja pozwalająca na „odkładanie” wypłaty takiego świadczenia w okresie znacznie odległym od nabycia statusu emeryta (np. po 5 latach od tego momentu) przeczyłaby charakterowi i celowi, dla którego ustanowiono omawianą odprawę.

$\mathrm{Z}$ treści art. 40 u.w.m.p.s. regulującego kwestię zbiegu prawa do odprawy emerytalnej i parlamentarnej wynika, że poseł nie ma prawa do pobrania obu odpraw w ramach jednej kadencji Sejmu ${ }^{14}$. Również w przepisach wykonawczych do ustawy o wykonywaniu mandatu posła i senatora jako regułę przyjęto uzależnienie wypłaty odprawy parlamentarnej od tego, czy w danej kadencji poseł otrzymał odprawę na podstawie art. 38 u.w.m.p.s. Na przykład w $\$ 11$ ust. 1 zarządzenia nr 4 Marszałka Sejmu z 19 maja 2011 r. w sprawie niektórych działań dotyczących posłów i ich biur poselskich, związanych z zakończeniem VI i roz-

13 W ten sposób np. M. Piankowski, Ochrona pracowniczych świadczeń majątkowych, Bydgoszcz 2001, s. 70, oraz Sąd Najwyższy np. w uzasadnieniu uchwały z 31 maja 1989 r., sygn. akt III PZP 52/88, OSNC 1989, nr 12, poz. 190.

14 W ten sposób J. Stelina, który podziela stanowisko autorki niniejszej opinii prezentowane m.in. w Zbieg uprawnień do odprawy emerytalno-rentowej i odprawy parlamentarnej [w:] Status posła, cz. II, Wybór ekspertyz prawnych do rozdziału 5 ustawy $z$ dnia 9 maja 1996 r. o wykonywaniu mandatu posła i senatora, red. I. Galińska-Rączy, Warszawa 2007, s. 418 i n. Szerzej na ten temat w komentarzu do art. 40 u.w.m.p.s. [w:] K. Grajewski, J. Stelina, P. Uziębło, Komentarz, op. cit., s. 461. 
poczęciem VII kadencji Sejmu ${ }^{15}$ uzależniono wypłatę odprawy parlamentarnej przysługującej na koniec VI kadencji m.in. od niewypłacenia odprawy emerytalnej (rentowej) w trakcie tej kadencji Sejmu.

Wśród przesłanek warunkujących prawo do odprawy emerytalno-rentowej przysługującej pracownikom, w orzecznictwie sądowym wskazuje się na związek czasowy między ustaniem stosunku pracy a przejściem na emeryturę (rentę) - tak: np. w wyroku Sądu Najwyższego z 20 września 2005 r. (sygn. akt II PK 20/05). W związku z tym, nie można przyjąć za prawidłową interpretacji według której, jeżeli poseł przechodzi na emeryturę np. w IV kadencji Sejmu i jest nadal posłem V i VI kadencji Sejmu, to uprawnienie do odprawy zachowuje przez cały okres sprawowania mandatu i może o nią wystąpić dopiero w VI kadencji. Ponadto z literalnego brzmienia fragmentu: „który przechodzi” (a nie np. przeszedł) wynika, że wypłata odprawy powinna mieć miejsce w okresie bliskim zdarzeniu, jakim jest przejście na emeryturę.

4. Odnosząc powyższe uwagi do podanego stanu faktycznego, należy przyjąć, że obaj posłowie nabyli prawo do odprawy emerytalnej w VI kadencji Sejmu (lata 2007-2011). Fakt, że nie wystąpili wówczas o wypłatę odprawy emerytalnej, skutkuje tym, że w obecnej VIII kadencji Sejmu mogliby oni ubiegać się o wypłatę tego świadczenia, pod warunkiem że roszczenie $\mathrm{z}$ tego tytułu nie uległo przedawnieniu. Ocena, czy nastąpiło przedawnienie, zależy od prawnej kwalifikacji odprawy jako świadczenia, do którego może mieć zastosowanie art. $291 \$ 1$ k.p. ${ }^{16}$ (przewidujący 3-letni termin przedawnienia) albo art. 118 k.c. ${ }^{17}$ (ustalający 10-letni termin przedawnienia).

5. Kwalifikacja omawianej odprawy emerytalnej w zakresie przedawnienia jest trudna, ponieważ przepisy odnoszące się do tego świadczenia nie są jednoznaczne, a w literaturze podkreśla się, że charakter tej odprawy jest sporny ${ }^{18}$.

15 Odprawe parlamentarna wypłaca się posłowi VI kadencji Sejmu, który nie został posłem lub senatorem nowej kadencji oraz któremu w trakcie VI kadencji Sejmu nie została wypłacona odprawa $w$ związku $z$ przejściem na emeryturę lub rentę, po złożeniu rozliczeń środków finansowych wypłaconych $w$ formie miesięcznych ryczałtów przeznaczonych na prowadzenie biura poselskiego w okresie trwania VI kadencji Sejmu oraz po rozliczeniu wszystkich innych zobowiązań wobec Kancelarii Sejmu ujętych w karcie rozliczeń, o której mowa $w \$ 10$. Analogiczny przepis byt zawarty we wcześniejszych i późniejszych zarządzeniach Marszałka wydawanych $w$ związu z zakończeniem kadencji.

16 Art. 291. \$1. Roszczenia ze stosunku pracy ulegaja przedawnieniu z uplywem 3 lat od dnia, w którym roszczenie stało się wymagalne.

17 Art. 118. Jeżeli przepis szczególny nie stanowi inaczej, termin przedawnienia wynosi lat dziesięć, a dla roszczeń o świadczenia okresowe oraz roszczeń związanych z prowadzeniem działalności gospodarczej - trzy lata.

18 Tak stwierdza J. Stelina w komentarzu do art. 38 u.w.m.p.s. [w:] K. Grajewski, J. Stelina, P. Uziębło, Komentarz, op. cit., s. 455. 
Wyrażono np. stanowisko, że świadczenie to należy w zakresie przywilejów egzekucyjnych kwalifikować tak, jak uposażenie poselskie na podstawie art. 27 u.w.m.p.s. ${ }^{19}$, czyli jako wynagrodzenie ze stosunku pracy chronione przed potrąceniami na podstawie art. 87 k.p. ${ }^{20}$. Jako uzasadnienie dla tego stanowiska przywołano ukształtowaną linię orzeczniczą, że odprawa emerytalno-rentowa przysługująca na podstawie przepisów prawa pracy jest wynagrodzeniem za pracę w rozumieniu przepisów o ochronie wynagrodzenia ${ }^{21}$. Jednocześnie stwierdzono, że: istnieje podstawa, by odprawę emerytalna $i$ odprawę rentowa, przysługujace

19 Art. 27. Uposażenie oraz dodatki, o których mowa w art. 26, sa traktowane jako wynagrodzenie ze stosunku pracy.

20 Art. 87. \$ 1. Z wynagrodzenia za prace - po odliczeniu składek na ubezpieczenia społeczne oraz zaliczki na podatek dochodowy od osób fizycznych - podlegaja potraceniu tylko następujące należności:

1) sumy egzekwowane na mocy tytułów wykonawczych na zaspokojenie świadczeń alimentacyjnych;

2) sumy egzekwowane na mocy tytułów wykonawczych na pokrycie należności innych niż świadczenia alimentacyjne;

3) zaliczki pieniężne udzielone pracownikowi;

4) kary pieniężne przewidziane $w$ art. 108.

$\$ 2$. Potrąceń dokonuje się $w$ kolejności podanej $w \$ 1$.

\$3. Potracenia moga być dokonywane w następujących granicach:

1) w razie egzekucji świadczeń alimentacyjnych - do wysokości trzech piątych wynagrodzenia;

2) w razie egzekucji innych należności lub potrącania zaliczek pieniężnych - do wysokości połowy wynagrodzenia.

$\$ 4$. Potracenia, o których mowa w\$ 1 pkt 2 i 3, nie moga w sumie przekraczać połowy wynagrodzenia, a łącznie z potraceniami, o których mowa $w \$ 1$ pkt 1 - trzech piątych wynagrodzenia. Niezależnie od tych potrąceń kary pieniężne potrąca się w granicach określonych $w$ art. 108.

\$5. Nagroda z zakładowego funduszu nagród, dodatkowe wynagrodzenie roczne oraz należności przysługujące pracownikom z tytułu udziału w zysku lub w nadwyżce bilansowej podlegaja egzekucji na zaspokojenie świadczeń alimentacyjnych do pełnej wysokości.

S6. (uchylony).

\$ 7. Z wynagrodzenia za pracę odlicza się, w pełnej wysokości, kwoty wypłacone w poprzednim terminie płatności za okres nieobecności w pracy, za który pracownik nie zachowuje prawa do wynagrodzenia.

$\$ 8$. Potraceń należności $z$ wynagrodzenia pracownika $w$ miesiącu, w którym sa wypłacane składniki wynagrodzenia za okresy dłuższe niż 1 miesiąc, dokonuje się od łącznej kwoty wynagrodzenia uwzględniajacej te składniki wynagrodzenia.

21 J. Stelina w komentarzu do art. 38, op. cit., s. 455, 456, powołuje wyrok SN z 17 lutego 2004 r., sygn. akt I PK 217/03, OSNP 2004, nr 24, poz. 419, w którym stwierdzono: Odprawa emerytalna (art. $92^{1}$ k.p.) oraz nagroda jubileuszowa (art. $77^{3} \$ 3$ pkt 3 k.p.) podlegają ochronie przed potraceniami (art. 87 k.p.) jak wynagrodzenie za pracę. 
na podstawie art. 38 ust. 1 komentowanej ustawy, traktować tak jak uposażenie $z$ wszelkim płynacymi stąd konsekwencjami w zakresie przywilejów egzekucyjnych. Poglad ten znajduje wsparcie $w$ tym, ze pobranie omawianej odprawy wyłacza prawo do analogicznej odprawy przysługujacej $z$ mocy przepisów prawa pracy ${ }^{22}$.

Przyjęcie stanowiska, że omawianą odprawę należy uwzględniać w zakresie przywilejów egzekucyjnych wynikających z prawa pracy (czyli że świadczenie to powinno podlegać ochronie, jak odprawa emerytalno-rentowa przysługująca pracownikom) skutkuje tym, że kwalifikację tę należy również w sposób konsekwentny odnosić do przepisów związanych z przedawnieniem roszczeń. Oznaczałoby to, że w omawianym stanie faktycznym ma zastosowanie art. $291 \$ 1$ k.p., czyli że nastąpiło przedawnienie roszczenia (odpowiednio w roku 2012 i 2013).

Inny pogląd został wyrażony w odniesieniu do odprawy parlamentarnej ${ }^{23}$, która tak jak odprawa emerytalna nie została uwzględniona w art. 27 u.w.m.p.s., stanowiącym, że: [u]posażenie oraz dodatki, o których mowa w art. 26, sa traktowane jako wynagrodzenie ze stosunku pracy. Z. Monkiewicz w opinii pt. Zajęcie odprawy parlamentarnej przez komornika ${ }^{24}$ uznaje, że w świetle powołanego przepisu tylko uposażenie i dodatki do niego są chronione na podstawie art. 87 k.p. Ze stanowiska tej autorki wynika, że odprawa parlamentarna jako świadczenie niemające charakteru uposażenia nie korzysta z ograniczeń egzekucji, jakim podlega wynagrodzenie za pracę. Odnosząc się do wyroku Sądu Najwyższego z 17 lutego 2004 r. (sygn. akt I PK 217/03), w którym uznano, że odprawa emerytalna podlega ochronie przed potrąceniami (art. 87 k.p.) tak, jak wynagrodzenie za pracę, Z. Monkiewicz stwierdza: Sąd Najwyższy wskazał również, iż także $w$ doktrynie prawa pracy przyjmuje się szerokie rozumienie pojęcia wynagrodzenie za prace dla celów ochrony przed potraceniami ze strony pracodawcy (por. J. Iwulski, W. Sanetra: „Kodeks pracy. Komentarz”, Warszawa 2003 tezy do art. 87; odmiennie jednak S. Płażek: „Problem dopuszczalności potrąceń z wierzytelnościami pracownika innymi niż wynagrodzenie", PiZS 1999 nr 12, s. 36). Być może oznaczałoby to możliwość dopuszczenia zastosowania analogicznej ochrony w stosunku do odprawy parlamentarnej, jednakże do możliwości takiej należy podejść z duża ostrożnością. Po pierwsze bowiem przepisy kodeksu pracy odnoszace się do wynagrodzenia za prace maja zastosowanie do posłów jedynie z mocy wyraźnego odesłania, które ograniczone jest do uposażenia i dodatków do niego (poseł nie pozostaje w stosunku pracy), a po drugie świadczenie to przysługuje wszystkim posłom, którzy nie zostali wybrani na następną kadencję, bez względu na to, czy w czasie

22 Ibidem, s. 456.

23 Przysługującej na podstawie art. 39 ust. 1 u.w.m.p.s., który stanowi: Posłowi i senatorowi $w$ zwiazku z zakończeniem kadencji przysługuje odprawa parlamentarna w wysokości trzech uposażeń. Odprawa nie przystuguje, jeżeli poseł lub senator został wybrany na następna kadencje.

24 Publikowanej w: Status posła, op. cit., s. 426-428. 
kadencji pozostawali oni $w$ stosunku pracy $w$ zakładzie pracy ( $i$ w czasie kadencji sejmu korzystali $z$ urlopu bezpłatnego), czy też nie i w zwiazku z tym, czy maja odpowiednie środki na zaspokojenie potrzeb po zakończeniu kadencji ${ }^{25}$.

Autorka powołuje również art. $833 \$ 2$ Kodeksu postępowania cywilnego, który stanowił, że uposażenia poselskie i senatorskie podlegają egzekucji w zakresie określonym w Kodeksie pracy ${ }^{26}$. Przyjęcie powyższej interpretacji będzie oznaczać, że zarówno w odniesieniu do odprawy parlamentarnej, jak i odprawy emerytalnej przysługującej posłom, należałoby stosować art. 118 k.c. ustalający 10-letni termin przedawnienia, nie zaś art. $291 \$ 1$ k.p.

6. Mając na względzie możliwość zastosowania odnośnie do terminu przedawnienia obu wskazanych interpretacji, należy dokonać szerszej analizy prawnego charakteru odprawy emerytalnej przysługującej na podstawie art. 38 u.w.m.p.s.

W literaturze podkreśla się, że dominujące znaczenie dla statusu parlamentarzystów ma pierwiastek publicznoprawny, a pozostawanie w zatrudnieniu o charakterze ustrojowym wyklucza: positkowe stosowanie przepisów regulujących stosunki zatrudnienia pracowniczego, cywilnoprawnego i służbowego, co oznacza, że wszelkie uprawnienia i obowiązki pozostające np. w związku $z$ wykonywaniem mandatu musza być uregulowane w przepisach ustrojowych ${ }^{27}$. Jednocześnie uznaje się, że pozostawanie parlamentarzystów w zatrudnieniu ustrojowym nie jest stosunkiem regulowanym przez prawo pracy, a uposażenie stanowi: rekompensate za specyficzna, niepracownicza prace parlamentarzysty i $w$ istocie petni role wynagrodzenia pracowniczego ${ }^{28}$.

Powyższe twierdzenia wskazują na znaczne trudności z definiowaniem charakteru świadczeń przysługujących parlamentarzystom, ponieważ z jednej strony mówi się o niemożności „posiłkowego stosowania” m.in. przepisów regulujących stosunki pracy (czyli, jak można przypuszczać, również przepisów odnoszących się do przedawnienia roszczeń), a z drugiej przypisuje uposażeniu poselskiemu (senatorskiemu) rolę wynagrodzenia pracowniczego.

Wskazane trudności interpretacyjne wynikają przede wszystkim $\mathrm{z}$ braku szczegółowych regulacji oraz nieprecyzyjności przepisów określających status prawny osób zajmujących kierownicze stanowiska państwowe, czyli osób pozo-

25 Ibidem.

26 W 2005 r. przepis ten obowiązywał w brzmieniu:

Art. 833. \$ 1. Wynagrodzenie ze stosunku pracy podlega egzekucji w zakresie określonym w przepisach Kodeksu pracy. (...)

$\$ 2$. Przepis $₫ 1$ stosuje się odpowiednio do uposażeń posłów i senatorów, należności członków rolniczych spółdzielni produkcyjnych i ich domowników z tytułu pracy w spółdzielni, wynagrodzeń członków spółdzielni pracy oraz wszystkich świadczeń powtarzających się, których celem jest zapewnienie utrzymania.

27 J. Stelina, Komentarz do art. 38, op. cit., s. 334.

28 J. Oniszczuk, w rozdziale Ustrojowo prawne zatrudnienie niepracownicze [w:] System prawa pracy, t. VII, Zatrudnienie niepracownicze, Warszawa 2015, s. 518. 
stających w tzw. stosunkach zatrudnienia konstytucyjnoprawnego ${ }^{29}$. W literaturze podkreśla się, że sytuacja prawna osób piastujących takie stanowiska jest niedookreślona ${ }^{30}$. Jest to zatrudnienie szczególne, zwane „ustrojowoprawnym” lub „konstytucyjnoprawnym” albo „ustrojowym (politycznym)”31, przy czym niektórzy autorzy uznają, że w zatrudnieniu takim pozostają wyłącznie posłowie i senatorowie zawodowi ${ }^{32}$, czyli parlamentarzyści pobierający uposażenie poselskie (senatorskie), a ich status wykazuje zasadnicze podobieństwa do stosunków pracy nawiązywanych na podstawie wyboru ${ }^{33}$.

W literaturze stwierdza się również, że wiele uregulowań ustawy o wykonywaniu mandatu posła i senatora nawiązuje do pojęć i instytucji prawa pracy, a te zapożyczenia mają służyć umożliwieniu i prawidłowej realizacji mandatu parlamentarnego ${ }^{34}$.

Wymienione okoliczności pozwalają na przyjęcie, że ustrojowoprawnemu zatrudnieniu, w jakim pozostają parlamentarzyści, należałoby przypisywać pewne cechy, które są zbliżone najbardziej do zatrudnienia pracowniczego, nie zaś cywilnoprawnego czy administracyjnoprawnego, a w związku z tym do świadczeń przysługujących posłom i senatorom o podobnym charakterze jak wynagrodzenie ze stosunku pracy (a takim jest odprawa emerytalna) należałoby stosować zasady przedawnienia obowiązujące w prawie pracy.

7. Nawet, jeżeli poselskiej odprawie emerytalnej nie przypisywać cech zbliżonych do wynagrodzenia ze stosunku pracy, można kwalifikować ją jako szczególne świadczenie socjalno-bytowe, co oznacza, że możliwe staje się posiłkowe

29 K. Grajewski i K. Stelina wskazują, że w ramach takiego zatrudnienia: osoba fizyczna wykonuje bądź bierze udział w wykonywaniu władzy publicznej w imieniu państwa. W sytuacji prawnej tej osoby dominują czynniki polityczne, zwłaszcza jeśli chodzi o obsadę i utratę danego stanowiska, nie występują natomiast typowe dla innych rodzajów zatrudnienia (głównie pracowniczego i służbowego) więzi o charakterze organizacyjnym (podporządkowanie $i$ dyspozycyjność). Poza parlamentarzystami w zatrudnieniu o charakterze ustrojowym pozostaja m.in. Prezydent RP, prezes Rady Ministrów oraz członkowie rządu, radni samorządowi, członkowie Rady Polityki Pieniężnej itp., K. Grajewski, J. Stelina, P. Uziębło, Komentarz, op. cit., s. 333.

30 Tak A. Dral, Sytuacja prawna osób zatrudnionych na kierowniczych stanowiskach państwowych - uwagi de lege lata $i$ de lege ferenda, http://www.wspia.eu/file/15644/05-Dral.pdf.

31 W ten sposób A. Dral, ibidem, który powołuje A. Kijowskiego, Konstytucyjnoprawne aspekty dopuszczalności pracy nieodpłatnej [w:] Konstytucyjne problemy prawa pracy i zabezpieczenia społecznego, red. H. Szurgacz, Wrocław 2005.

32 A. Dral, Sytuacja prawna, op. cit.

33 W ten sposób W. Sanetra, Uwagi w kwestii zakresu podmiotowego kodeksu pracy [w:] Prawo pracy a wyzwania XXI wieku. Księga jubileuszowa profesora Tadeusza Zielińskiego, Warszawa 2002, s. 310, przywołuję za A. Dralem.

34 Tak: J. Oniszczuk, Ustrojowo prawne zatrudnienie, op. cit., s. 510-512. Autor ten wskazuje art. 25, 27 i 28 u.w.m.p.s. 
odwołanie do orzecznictwa odnoszącego się np. do przedawnienia świadczeń z zakładowego funduszu świadczeń socjalnych. Sąd Najwyższy w wyroku z 4 lipca 2007 r. (sygn. akt II PK 25/07) ) $^{35}$ uznał, że sprawa o roszczenie pracownika z zakładowego funduszu świadczeń socjalnych jest sprawą z zakresu prawa pracy i roszczenie to podlega przedawnieniu, tak jak roszczenie ze stosunku pracy (czyli na podstawie art. 291 \$ 1 k.p.). Także w wyroku z 10 kwietnia 2013 r. (sygn. akt II PK 272/12 ${ }^{36}$ SN stwierdził, że przedawnieniu określonemu w art. $291 \S 1$ k.p. ulegają roszczenia związku zawodowego o zwrot zakładowemu funduszowi świadczeń socjalnych środków wydatkowanych niezgodnie z przepisami ustawy lub o przekazaniu należnych środków na fundusz (art. 8 ust. 3 ustawy z 4 marca 1994 r. o zakładowym funduszu świadczeń socjalnych).

Sąd Najwyższy w tym drugim wyroku przypomniał, że w piśmiennictwie poświęconym przedawnieniu roszczeń w prawie pracy jedynie wyjątkowo dopuszczane jest stosowanie przepisów Kodeksu cywilnego o przedawnieniu. Sąd Najwyższy odwołał się przy tym do poglądu, że przepisy Kodeksu cywilnego mają posiłkowe zastosowanie wtedy, gdy w prawie pracy nie ma ani przepisu, który by normował dane zagadnienie wprost, w ramach instytucji prawnej, w skład której to zagadnienie wchodzi, ani przepisu, który odnosiłby się do podobnego stanu faktycznego.

Odnosząc powyższe do rozważanej kwestii, można stwierdzić, że w związku z tym, że odprawa emerytalno-rentowa przysługująca posłom jest świadczeniem podobnym do odprawy przysługującej pracownikom na podstawie art. $92^{1} \$ 1$ k.p. ${ }^{37}$ albo co najmniej świadczeniem o charakterze socjalnym związanym z pełnieniem mandatu, przedawnienie roszczenia $\mathrm{z}$ tego tytułu per analogiam ulegnie przedawnieniu jak roszczenia ze stosunku pracy albo roszczenia związane ze stosunkiem pracy $^{38}$, czyli w terminie 3-letnim przewidzianym w art. $291 \S 1$ k.p.

\section{Podsumowanie}

- Parlamentarzyści pozostają w niepracowniczym tzw. zatrudnieniu ustrojowym, które, tak jak w przypadku osób zajmujących kierownicze stanowiska państwowe, nie zostało uregulowane w sposób precyzyjny. Jednocześnie nie

35 OSNP 2008, nr 17-18, poz. 251.

36 OSNP 2014, nr 1, poz. 7.

37 K. Grajewski, J. Stelina, Szczególne uprawnienie pracownicze posłów i senatorów, „Przegląd Sejmowy” 2005, nr 1, s. 32, stwierdzają, że prawo do odprawy z art. 38 ust. 1 u.w.m.p.s. jest uprawnieniem zbliżonym (podobnym) do uprawnień pracowniczych.

38 Znamiennym rozstrzygnięciem dla rozważanego problemu jest uchwała 7 sędziów Sądu Najwyższego z 21 listopada 2012 r. (sygn. akt I PZP 1/12, OSNP 2013, nr 11-12, poz. 123), w której uznano, że roszczenie o odszkodowanie od pracodawcy z tytułu utraty prawa do nieodpłatnego nabycia akcji ulega przedawnieniu na podstawie art. $291 \$ 1$ k.p. 
jest jasny charakter odprawy emerytalnej przysługującej na podstawie art. 38 ust. 1 u.w.m.p.s. W literaturze wskazuje się, że jest to świadczenie, które należy traktować jak uposażenie ze wszystkimi tego konsekwencjami np. w zakresie przywilejów egzekucyjnych, czyli że powinno ono podlegać ochronie jak odprawa emerytalno-rentowa przysługująca pracownikom. Stwierdzenie to można odnosić do przepisów związanych z przedawnieniem roszczeń. W związku z tym możliwa jest interpretacja, zgodnie z którą w przypadku pracowniczej odprawy emerytalnej do odprawy przysługującej posłom należy stosować 3-letni termin przedawnienia wynikający z art. $291 \$ 1$ k.p.

- Ponieważ odprawa przysługująca na podstawie art. 38 ust. 1 u.w.m.p.s. nie została uwzględniona w jej art. 27 (czyli m.in. nie podlega ochronie przed egzekucją wynikającą z art. 87 k.p.), możliwa jest również inna interpretacja, uznająca, że świadczenie to (jako świadczenie niebędące wynagrodzeniem ani świadczeniem zrównanym $\mathrm{z}$ wynagrodzeniem) nie podlega przedawnieniu w terminie 3-letnim (na podstawie art. $291 \S 1$ k.p.), ale w terminie 10-letnim określonym w art. 118 k.c.

- Mając na względzie możliwość przypisywania zatrudnieniu ustrojowemu, w jakim pozostają posłowie, pewnych cech, które są zbliżone najbardziej do zatrudnienia pracowniczego, nie zaś cywilnoprawnego, a poselskiej odprawie emerytalnej charakteru podobnego do pracowniczej odprawy emerytalnej (uznawanej przez doktrynę i orzecznictwo za wynagrodzenie ze stosunku pracy), należałoby opowiadać się za stosowaniem 3-letniego terminu przedawnienia obowiązującego w prawie pracy.

\section{Bibliografia}

Dral A., Sytuacja prawna osób zatrudnionych na kierowniczych stanowiskach państwowych - uwagi de lege lata $i$ de lege ferenda, http://www.wspia.eu/file/15644/05-Dral. pdf.

Grajewski K., Stelina J., Szczególne uprawnienie pracownicze posłów i senatorów, „Przegląd Sejmowy” 2005, nr 1.

Iwulski J., Sanetra W., Tezy do art. 87 [w:] J. Iwulski, W. Sanetra, Kodeks pracy. Komentarz, Warszawa 2003.

Kijowski A., Konstytucyjnoprawne aspekty dopuszczalności pracy nieodpłatnej [w:] Konstytucyjne problemy prawa pracy i zabezpieczenia społecznego, red. H. Szurgacz, Wroclaw 2005.

Oniszczuk J., Ustrojowo prawne zatrudnienie niepracownicze [w:] System prawa pracy, t. VII, Zatrudnienie niepracownicze, red. K.W. Baran, Warszawa 2015.

Piankowski M., Ochrona pracowniczych świadczeń majątkowych, Bydgoszcz 2001.

Płażek S., Problem dopuszczalności potrąceń z wierzytelnościami pracownika innymi niż wynagrodzenie, „Praca i Zabezpieczenie Społeczne” 1999, nr 12. 
Rycak A., Komentarz do art. 38 ust. 1 ustawy o pracownikach samorzadowych [w:] Ustawa o pracownikach samorzadowych. Komentarz, A. Rycak, M. Rycak, J. Stelina, J. Stępień, Warszawa 2016.

Sanetra W., Uwagi w kwestii zakresu podmiotowego kodeksu pracy [w:] Prawo pracy a wyzwania XXI wieku. Księga jubileuszowa profesora Tadeusza Zielińskiego, Warszawa 2002.

Stelina J., Komentarz do art. 38 [w:] Komentarz do ustawy o wykonywaniu mandatu posła i senatora, K. Grajewski, J. Stelina, P. Uziębło, Warszawa 2014.

Stelina J., Zbieg uprawnień do odprawy emerytalno-rentowej i odprawy parlamentarnej [w:] Status posła, cz. II, Wybór ekspertyz prawnych do rozdziału 5 ustawy z dnia 9 maja 1996 r. o wykonywaniu mandatu posła i senatora, red. I. Galińska-Rączy, Warszawa 2007.

Wagner B. [w:] Kodeks pracy. Komentarz, L. Florek (red.), 2017, LEX. 